\title{
Effects of Melatonin-Soaked Seeds on the Cadmium Accumulation in Broadbean (Vicia faba) Seedlings
}

\author{
Jing Yang ${ }^{1, a}$, Cheng Chen ${ }^{2, b}$ and Lijin Lin ${ }^{3, c *}$ \\ ${ }^{1}$ College of Horticulture, Sichuan Agricultural University, Chengdu, Sichuan, China \\ ${ }^{2}$ College of Economics, Sichuan Agricultural University, Chengdu, Sichuan, China \\ ${ }^{3}$ Institute of Pomology and Olericulture, Sichuan Agricultural University, Chengdu, Sichuan, China \\ a769751475@qq.com, b8521153@qq.com, '1lj800924@qq.com
}

${ }^{*}$ Corresponding author. Jing Yang and Cheng Chen contributed equally to this work.

\begin{abstract}
Keywords: Melatonin; Broadbean (Vicia faba); Cadmium; Growth
Abstract: In order to discuss the melatonin (MT) on the growth and cadmium (Cd) accumulation in vegetables, broadbean (Vicia faba) seeds were soaked in five doses (0, 50, 100, 150 and 200 $\mu \mathrm{mol} / \mathrm{L}$ ) of MT and then planted in pots containing Cd-contaminated soil. Different doses of MT increased the biomasses of broadbean seedlings' roots and shoots compared with the control, with $200 \mu \mathrm{mol} / \mathrm{L}$ of MT producing the maximum values. MT effectively decreased the Cd contents in roots and shoots of broadbean seedlings compared with the control, and the maximum reduction rate of $29.29 \%$ occurred at the $200-\mu \mathrm{mol} / \mathrm{L}$ MT dose. Thus, MT could promote broadbean growth and reduce $\mathrm{Cd}$ accumulation in broadbean, with $200 \mu \mathrm{mol} / \mathrm{L}$ being the optimum dose in this experiment.
\end{abstract}

\section{Introduction}

Melatonin (MT) is an indole amine hormone that can regulate plant photoperiods and improve the plants' responses to adverse environmental conditions, such as heavy metals, ultraviolet radiation, temperature changes and other functions [1]. Under heavy metal stress, exogenous MT can chelate a high concentration of metal ions, preventing them from damaging biological macromolecules, and it also produces antioxidant protection against seeds and seedlings [2]. The application of an appropriate exogenous MT concentration can promote the growth of young rice buds under nickel (Ni) stress and alleviate the toxicity of Ni to rice seedlings [3]. Under high-temperature stress, MT inhibits reactive oxygen species (ROS) production in cucumber seedlings, improves antioxidant enzyme activities, inhibits the reduction of chlorophyll a, and increases the chlorophyll $\mathrm{a} / \mathrm{b}$ ratio and carotenoid content, which reduces the damage caused by high-temperature stress on cucumber seedlings and maintains the photosynthetic rate at a relatively high level [4-5]. MT can also enhance the resistance of tomato to cadmium $(\mathrm{Cd})$ by improving antioxidant enzyme activities and promoting the integration and isolation of Cd in plants [6]. Thus, MT can alleviate the damage to plants caused by heavy metal stress. In this research, the effects of MT on growth and Cd-related characteristics of broadbean seedlings were studied to determine whether MT can reduce Cd accumulation in broadbean seedlings.

\section{Materials and Methods}

Materials. Local varieties of broadbean grown in Chengdu, Sichuan Province, China were used in this study. The soil samples were fluvo-aquic soils, which were collected from the Chengdu Campus Farm of Sichuan Agricultural University $\left(30^{\circ} 42^{\prime} \mathrm{N}, 103^{\circ} 51^{\prime} \mathrm{E}\right)$ in October 2015 . The soil basic properties and its Cd content were described in Liu et al. (2015) [7]. Then, $0.5 \mathrm{~kg}$ of air-dried soil was placed into each polyethylene pot (10-cm high, $8-\mathrm{cm}$ diameter). $\mathrm{Cd}\left(\mathrm{CdCl}_{2} \cdot 2.5 \mathrm{H}_{2} \mathrm{O}\right)$ was added to the soil samples at a dose of $10 \mathrm{mg} / \mathrm{kg}$ according to [8]. The soil moisture was maintained at $80 \%$ of field capacity for one month.

Experimental Design. In November 2015, the seeds of broadbean were soaked in different doses $(0,50,100,150$ and $200 \mu \mathrm{mol} / \mathrm{L})$ of MT for $48 \mathrm{~h}$. A $50-\mathrm{mL}$ solution soaked approximately 15 seeds. 
Then, the seeds were placed in an incubator to germinate at $26^{\circ} \mathrm{C}$ for $48 \mathrm{~h}$, and four uniform seeds with buds were transplanted into the prepared soil of each pot in the greenhouse of the Chengdu Campus Farm. Every treatment was replicated four times (four pots). We watered every day to keep the soil moist. When the broadbean seedlings had grown for one month (December 2015), the whole broadbean seedlings were harvested and washed with tap water and deionized water. The fresh weights of the roots, stems and leaves were weighted. After that, the fresh organ of plant samples $(5.000 \mathrm{~g})$ were ground into homogenates, digested in $\mathrm{HNO}_{3}: \mathrm{HClO}_{4}$, and determined the $\mathrm{Cd}$ concentration using an iCAP 6300 ICP spectrometer (Thermo Scientific, Waltham, MA, USA) [9]. The measured values of the Cd contents were checked according to Zhang et al. (2011) [10].

Statistical Analyses. Data were analyzed using SPSS 13.0 statistical software (IBM, Chicago, IL, USA).

\section{Results and Discussion}

Biomasses of Broadbean Seedlings. Compared with the control, soaking seeds in different MT concentrations increased the biomasses of the root, leaf and shoot of broadbean seedlings (Table 1). The $50-\mu \mathrm{mol} / \mathrm{L}$ MT dose had no significant effects on the stem biomass of broadbean seedlings compared with the control, but 100, 150 and 200- $\mu \mathrm{mol} / \mathrm{L}$ MT doses increased that the stem biomass. When the MT doses were 100, 150 and $200 \mu \mathrm{mol} / \mathrm{L}$, the shoot biomasses of broadbean seedlings significantly increased by $9.47 \%, 13.49 \%$ and $19.20 \%$, respectively, compared with the control. Thus, the $200-\mu \mathrm{mol} / \mathrm{L}$ MT dose produced the optimum results in this experiment.

Table 1 Biomasses of broadbean seedlings

\begin{tabular}{|c|c|c|c|c|}
\hline $\begin{array}{c}\text { Melatonin } \\
\text { concentrations } \\
(\mu \mathrm{mol} / \mathrm{L})\end{array}$ & $\begin{array}{c}\text { Roots } \\
(\mathrm{g} / \text { plant fresh wt })\end{array}$ & $\begin{array}{c}\text { Stems } \\
(\mathrm{g} / \text { plant fresh wt })\end{array}$ & $\begin{array}{c}\text { Leaves } \\
(\mathrm{g} / \text { plant fresh wt })\end{array}$ & $\begin{array}{c}\text { Shoots } \\
(\mathrm{g} / \text { plant fresh wt })\end{array}$ \\
\hline 0 & $5.68 \pm 0.03 \mathrm{~d}$ & $3.91 \pm 0.02 \mathrm{~b}$ & $4.31 \pm 0.05 \mathrm{e}$ & $8.23 \pm 0.05 \mathrm{e}$ \\
\hline 50 & $5.95 \pm 0.04 \mathrm{c}$ & $3.95 \pm 0.03 \mathrm{~b}$ & $4.58 \pm 0.06 \mathrm{~d}$ & $8.53 \pm 0.06 \mathrm{~d}$ \\
\hline 100 & $6.05 \pm 0.05 \mathrm{c}$ & $4.10 \pm 0.04 \mathrm{a}$ & $4.91 \pm 0.07 \mathrm{c}$ & $9.01 \pm 0.07 \mathrm{c}$ \\
\hline 150 & $6.25 \pm 0.02 \mathrm{~b}$ & $4.15 \pm 0.01 \mathrm{a}$ & $5.19 \pm 0.08 \mathrm{~b}$ & $9.34 \pm 0.06 \mathrm{~b}$ \\
\hline 200 & $6.58 \pm 0.03 \mathrm{a}$ & $4.23 \pm 0.02 \mathrm{a}$ & $5.59 \pm 0.09 \mathrm{a}$ & $9.81 \pm 0.06 \mathrm{a}$ \\
\hline
\end{tabular}

Values are means $( \pm$ SE) of four replicate pots. Significant differences (indicated by different lowercase letters) within a column are based on a one-way analysis of variance with the least significant difference test $(p<0.05)$, and followed by the post-hoc test.

Cd Content in Broadbean Seedlings. Compared with the control, MT decreased the Cd content in the roots of broadbean seedlings, but there were no significant differences among the 50-, 100-, 150- and 200- $\mu \mathrm{mol} / \mathrm{L}$ MT doses (Table 2). MT had no significant effects on the Cd contents in the stems of broadbean seedlings compared with the control. When the doses of MT were 50, 100, 150 and $200 \mu \mathrm{mol} / \mathrm{L}$, compared with the control, the Cd contents in the leaves decreased by $11.29 \%$, $20.16 \%, 34.27 \%$ and $40.32 \%$, respectively. For the Cd content in shoots, the $50-\mu \mathrm{mol} / \mathrm{L}$ MT dose had no significant effects on the Cd contents in the shoots compared with the control, and 100-, 150- and 200- $\mu \mathrm{mol} / \mathrm{L}$ MT doses decreased the Cd contents in the shoots. When the doses of MT were 100,150 and $200 \mu \mathrm{mol} / \mathrm{L}$, the Cd contents in the shoots decreased by $13.64 \%, 24.75 \%$ and $29.29 \%$, respectively, compared with the control. Thus, MT could effectively decrease the Cd content in broadbean seedlings. 


\section{Discussion}

Under stress conditions, MT plays an important role in promoting plant growth [11-13]. Other studies indicated that only low MT levels promote plant growth, while high MT levels inhibit growth [14-15]. In this study, 100-, 150- and 200- $\mu \mathrm{mol} / \mathrm{L}$ MT doses increased the biomass of broadbean seedlings, while the $50-\mu \mathrm{mol} / \mathrm{L}$ MT dose had no significant effect. This was not completely consistent with previous studies [11-15]. This might be related to the different sensitivities of plants to MT and requires further study. In this experiment, MT effectively decreased the $\mathrm{Cd}$ contents in roots, leaves, and shoots of broadbean seedlings, but not in stems, which might be related to the distribution of $\mathrm{Cd}$ in different broadbean organs [6], and the integration and isolation of $\mathrm{Cd}$ in plants [6]. Thus, MT can reduce Cd accumulation in broadbean and should be used in broadbean production areas having Cd-contaminated soil.

Table 2 Cadmium contents in broadbean seedlings

\begin{tabular}{|c|c|c|c|c|}
\hline $\begin{array}{c}\text { Melatonin } \\
\text { concentrations } \\
(\mu \mathrm{mol} / \mathrm{L})\end{array}$ & $\begin{array}{c}\text { Roots } \\
(\mathrm{mg} / \mathrm{kg} \text { fresh } \mathrm{wt})\end{array}$ & $\begin{array}{c}\text { Stems } \\
(\mathrm{mg} / \mathrm{kg} \text { fresh } \\
\mathrm{wt})\end{array}$ & $\begin{array}{c}\text { Leaves } \\
(\mathrm{mg} / \mathrm{kg} \text { fresh } \\
\mathrm{wt})\end{array}$ & $\begin{array}{c}\text { Shoots } \\
(\mathrm{mg} / \mathrm{kg} \text { fresh } \\
\mathrm{wt})\end{array}$ \\
\hline 0 & $3.56 \pm 0.04 \mathrm{a}$ & $0.143 \pm 0.006 \mathrm{a}$ & $0.248 \pm 0.004 \mathrm{a}$ & $0.198 \pm 0.002 \mathrm{a}$ \\
\hline 50 & $3.05 \pm 0.05 \mathrm{~b}$ & $0.142 \pm 0.005 \mathrm{a}$ & $0.220 \pm 0.006 \mathrm{~b}$ & $0.184 \pm 0.004 \mathrm{ab}$ \\
\hline 100 & $2.92 \pm 0.05 \mathrm{~b}$ & $0.140 \pm 0.003 \mathrm{a}$ & $0.198 \pm 0.008 \mathrm{c}$ & $0.171 \pm 0.004 \mathrm{~b}$ \\
\hline 150 & $2.91 \pm 0.08 \mathrm{~b}$ & $0.131 \pm 0.002 \mathrm{a}$ & $0.163 \pm 0.009 \mathrm{~d}$ & $0.149 \pm 0.005 \mathrm{c}$ \\
\hline 200 & $2.82 \pm 0.01 \mathrm{~b}$ & $0.129 \pm 0.005 \mathrm{a}$ & $0.148 \pm 0.004 \mathrm{~d}$ & $0.140 \pm 0.003 \mathrm{c}$ \\
\hline
\end{tabular}

Values are means $( \pm$ SE) of four replicate pots. Significant differences (indicated by different lowercase letters) within a column are based on a one-way analysis of variance with the least significant difference test $(p<0.05)$, and followed by the post-hoc test.

\section{Conclusions}

Different doses of MT increased the biomasses of broadbean seedlings' roots and shoots compared with the control, with $200 \mu \mathrm{mol} / \mathrm{L}$ of MT producing the maximum values. MT effectively decreased the $\mathrm{Cd}$ contents in roots and shoots of broadbean seedlings compared with the control, and the maximum reduction rate of $29.29 \%$ occurred at the $200-\mu \mathrm{mol} / \mathrm{L}$ MT dose. Thus, MT could promote broadbean growth and reduce Cd accumulation in broadbean, with $200 \mu \mathrm{mol} / \mathrm{L}$ being the optimum dose in this experiment.

\section{Acknowledgements}

This work was financially supported by the Application Infrastructure Project of Science and Technology Department of Sichuan Province (2016JY0258).

\section{References}

[1] Y. Zhao, D.H. Wang and X.Y. Zhao: Acta Botanica Boreali-Occidentalia Sinica Vol. 34 (2014), p. 196.

[2] J.Q. Zuo, J.H. Xie, Y.X. Xue, H. Feng, J.N. Xu and X. Huang: Genomics and Applied Biology Vol. 33 (2014), p. 709.

[3] S.X. Liu, Y.Z. Huang, Z.J. Luo, Y.C. Huang and H. Jiang: Environmental Science Vol. 38 (2017), p. 1675.

[4] X.D. Xu, Y. Sun, B. Sun, J. Zhang and X.Q. Guo: Chinese Journal of Applied Ecology Vol. 21 (2010), p. 1295. 
[5] X.D. Xu, Y. Sun, X.Q. Guo, B. Sun and J. Zhang: Acta Agriculturae Nucleatae Sinica Vol. 25 (2011), p. 179.

[6] M.K. Hasan, G.J. Ahammed, L. Yin, K. Shi, X. Xia, Y. Zhou, J. Yu and J. Zhou: Frontiers in Plant Science Vol. 6 (2015), p. 601.

[7] Y. Liu, L. Lin, Q. Jin and X. Zhu: Environmental Progress \& Sustainable Energy Vol. 34 (2015), p. 663.

[8] L. Lin, M. Liao, Y. Ren, L. Luo, X. Zhang, D. Yang and J. He: PLoS ONE Vol. 9 (2014), p. e114957.

[9] S.D. Bao: Soil Agrochemical Analysis (China Agriculture Press, Beijing, China 2000).

[10] X.F. Zhang, H.P. Xia, Z.A. Li, P. Zhuang and B. Gao: Journal of Hazardous Materials Vol. 189 (2011), p. 414.

[11]N. Zhang, B. Zhao, H.J. Zhang, S. Weeda, C. Yang, Z.C. Yang, S. Ren and Y.D. Guo: Journal of Pineal Research Vol. 54 (2013), p. 15.

[12]N. Zhang, Q. Jiang, D.B. Li, L.T. Cai, H.J. Zhang, W.J. Si, X.F. Fan and Y.D. Guo: Journal of China Agricultural University Vol. 19 (2014), p. 54.

[13] S.X. Liu, Y.Z. Huang, Z.J. Luo, Y.C. Huang, Q.L. Bao, P.P. Wang, B. Yuan and W.H. Li: Journal of Agro-environment science Vol. 35 (2016), p. 1034.

[14]Q. Chen, W.B. Qi, R.J. Reiter, W. Wei and B.M. Wang: Journal of Plant Physiology Vol. 166 (2009), p. 324.

[15] V.N. Sarropoulou, I.N. Therios and K.N. Dimassi-Theriou: Journal of Pineal Research Vol. 52 (2012), p. 38.

[16]X. Yao: Study on the Transformation and Bioavailability of Cadmium in Modified Soil and Vicia faba with Application of Municipal Sludge (Master Thesis, Lanzhou University, China 2016). 